\title{
Ocena przydatności obrazowania dyfuzji metodą rezonansu magnetycznego $w$ diagnostyce różnicowej łagodnych i złośliwych zmian ogniskowych w wątrobie
}

\author{
Justyna Rembak-Szynkiewicz', Barbara Bobek-Billewicz', Michał Jarząb², \\ Marek Jurkowski ${ }^{4}$, Ewa Stobiecka ${ }^{3}$, Dorota Poninkiewska ${ }^{3}$, Iwona Pawlik ${ }^{1}$
}

Cel pracy. Nieinwazyjna diagnostyka różnicowa zmian ogniskowych w wątrobie - mimo stosowania wielu technik obrazowania - często jest nadal zadaniem trudnym, tym ważniejszym, że biopsja wątroby jest obarczona ryzykiem powikłań. Z drugiej strony upowszechnienie nieinwazyjnych metod radiologii i diagnostyki obrazowej przyczyniło się do wzrostu wykrywalności także przypadkowych zmian ogniskowych w wątrobie. Nie dziwi więc poszukiwanie nowych, bardziej skutecznych metod różnicowania zmian łagodnych i złośliwych w wątrobie. Celem pracy jest ocena wartości diagnostycznej dyfuzji obrazowanej metodą rezonansu magnetycznego (DW MRI — Diffusion Weighted Magnetic Resonance Imaging) w różnicowaniu łagodnych i złośliwych zmian ogniskowych w wątrobie.

Materiał i metody. Do pracy włączono obrazy uzyskane od 51 chorych, u których w wątrobie stwierdzono w badaniu MR zmiany ogniskowe, a następnie potwierdzono ich charakter (weryfikacja mikroskopowa, obserwacja). Przeanalizowano obrazy 95 zmian ogniskowych w wątrobie (71 zmian złośliwych, 24 łagodne). Oprócz standardowego badania MR wątroby wykonywano obrazowanie dyfuzji metodą EPI SE (Echo Planar Imaging Spin Echo), warstwą grubości 5 lub $6 \mathrm{~mm}$. Maksymalna wartość współczynnika b wynosiła $1000 \mathrm{~s} / \mathrm{mm}^{2}$, minimalna $0 \mathrm{~s} / \mathrm{mm}^{2}$. W pracy oceniano: występowanie ograniczenia dyfuzji, bezwzględną wartość pozornego współczynnika dyfuzji ADC (Apparent Diffusion Coefficient), spadek IS (intensywność sygnału) w obrazach DW MRI ze wzrostem wartości współczynnika b.

Wyniki. Stwierdzenie lub wykluczenie ograniczenia dyfuzji jest zwykle pierwszym, i jak wykazują uzyskane rezultaty, skutecznym krokiem w różnicowaniu zmian łagodnych i złośliwych w wątrobie. W badanym materiale ograniczenie dyfuzji występowało statystyczne istotnie częściej w zmianach złośliwych (87,3\%) niżłagodnych $(12,5 \%)(p<0,0001)$. Wykorzystując ograniczenie dyfuzji jako kryterium złośliwości, prawidłowo zaklasyfikowano 87,4\% zmian (62 złośliwe i 21 łagodnych). W analizowanym materiale średnia minADC zmian złośliwych $\left(0,92 \times 10^{-3} \mathrm{~mm}^{2} / \mathrm{s}\right)$ była statystycznie istotnie niższa niż zmian łagodnych $\left(1,48 \times 10^{-3} \mathrm{~mm}^{2} / \mathrm{s}\right)(\mathrm{p}<0,0001)$. W praktyce klinicznej istotnym jest znalezienie wartości współczynnika ADC rozdzielającej zmiany łagodne i złośliwe. Wyznaczona za pomocą krzywej charakterystyki odbiornika (ROC) wartość $A D C$ odcinająca zmiany łagodne i złośliwe wynosiła $1,04 \times 10^{-3} \mathrm{~mm}^{2} / \mathrm{s}$. Uznając zmiany o wartości $A D C>1,04 \times 10^{-3} \mathrm{~mm}^{2} / \mathrm{s}$ za łagodne, a o wartości $A D C \leq 1,04 \times 10^{-3} \mathrm{~mm}^{2} / \mathrm{s}$ za złośliwe, prawidłowo zakwalifikowano $75,8 \%$ zmian.

Wnioski. Uzyskane wyniki wskazują, że w różnicowaniu łagodnych i złośliwych zmian ogniskowych w wątrobie najbardziej przydatnym parametrem obrazowania DWI MR jest ograniczenie dyfuzji — jako marker zmian złośliwych.

\footnotetext{
${ }^{1}$ Zakład Radiologii i Diagnostyki Obrazowej

${ }^{2}$ III Klinika Radioterapii i Chemioterapii

${ }^{3}$ Zakład Patologii Nowotworów

Centrum Onkologii — Instytut im. Marii Skłodowskiej-Curie Oddział w Gliwicach

${ }^{4}$ Katedra Analityki Medycznej

Uniwersytet Warmińsko-Mazurski w Olsztynie
} 


\section{The value of diffusion-weighted magnetic resonance imaging (DW MRI) in differentiating benign and malignant liver lesions}

Introduction. Despite the use of multiple diagnostic imaging techniques, a non-invasive differential diagnosis of focal lesions in the liver is still a challenging task. It is even more significant, considering the risk of complications related to liver biopsy. On the other hand, the availability of non-invasive radiological and diagnostic imaging methods has resulted in the increased detectability of incidental hepatic lesions. Therefore, further investigation of newer and more effective methods of differentiating benign from malignant hepatic lesions is extremely useful. The aim of the study was to assess the diagnostic value of Diffusion-Weighted Magnetic Resonance Imaging (DW MRI) in differentiating benign from malignant focal lesions in the liver.

Material and methods. Fifty one patients with hepatic lesions detected by magnetic resonance (MR) examination were enrolled in the study. Each lesion was then verified histopathologically, cytologically, or by observation. Ninety five (71 malignant and 24 benign) hepatic focal lesions were analysed. Apart from a standard MR liver examination, an echo planar imaging spin echo diffusion weighted sequence was performed, with a slice thickness of 5 or $6 \mathrm{~mm}$. The maximal b-value was $1000 \mathrm{~s} / \mathrm{mm}^{2}$ and the minimal $0 \mathrm{~s} / \mathrm{mm}^{2}$.

In the study, the following were assessed: the presence of restricted diffusion, an absolute ADC (apparent diffusion coefficient) value, the decrease of signal intensity in DW MRI with an increase in the b-value.

Results. Confirming or ruling out the restricted diffusion is usually the first effective step in differentiating benign from malignant hepatic lesions, as indicated in the study results. In the material analysed, the diffusion restriction occurred statistically significantly more frequently in malignant $(87.3 \%)$ compared to benign lesions $(12.5 \%),(p<0.0001)$. Using the diffusion restriction as a criterion for malignancy, $87.4 \%$ lesions were correctly classified (62 malignant and 21 benign lesions). In the material analysed, the mean minADC value in malignant lesions $\left(0.92 \times 10^{-3} \mathrm{~mm}^{2} / \mathrm{s}\right)$ was statistically significantly lower compared to benign lesions $\left(1.48 \times 10^{-3} \mathrm{~mm}^{2} / \mathrm{s}\right)(\mathrm{p}<0.0001)$. In clinical practice, it is important to determine the ADC reference values for benign and malignant lesions. The boundary ADC value differentiating benign from malignant lesions estimated when using the ROC curve was $1.04 \times 10^{-3} \mathrm{~mm}^{2} / \mathrm{s}$. Considering lesions with an $A D C$ value $>1.04 \times 10^{-3} \mathrm{~mm}^{2} / \mathrm{s}$ to be benign and lesions with $A D C$ value $\leq 1.04 \times 10^{-3} \mathrm{~mm}^{2} / \mathrm{s}$ to be malignant, $75.8 \%$ lesions were correctly classified.

Conclusions. The results obtained indicate that restricted diffusion, as a marker for malignant lesions, has the highest value in DW MRI in differentiating benign from malignant lesions in the liver.

NOWOTWORY Journal of Oncology 2014; 64, 5: 377-382

Słowa kluczowe: łagodne i złośliwe zmiany w wątrobie, obrazowanie dyfuzji metodą rezonansu magnetycznego (DW MRI), ograniczenie dyfuzji, pozorny współczynnik dyfuzji ADC

Key words: benign and malignant focal liver lesions, diffusion-weighted MR imaging, restricted diffusion, apparent diffusion coefficient (ADC)

\section{Wstęp}

Nieinwazyjna diagnostyka różnicowa zmian ogniskowych w wątrobie mimo stosowania wielu technik obrazowania jest nadal zadaniem trudnym i tym ważniejszym, że biopsja wątroby jest obarczona ryzykiem powikłań, a ponadto często niemożliwa do wykonania [1]. Jedną z metod obrazowania budzącą w ostatnich latach wielkie nadzieje w radiologii onkologicznej jest obrazowanie MR zależne od dyfuzji (Diffusion Weighted Magnetic Resonance Imaging - DW MRI). Obrazowanie MR zależne od dyfuzji opisuje mikrostrukturę tkanki i dostarcza informacji na temat gęstości komórkowej i integralności błon komórkowych [2-6].

Uważa się, że DW MRI pozwala nie tylko odróżnić tkankę prawidłową od nowotworu, ale - co szczególnie istotne — nowotwór od procesu zapalnego.
W guzach złośliwych w wyniku zwiększonej ilości komórek w jednostce objętości oraz zwiększenia stopnia nieregularności przestrzeni zewnątrzkomórkowej dochodzi do ograniczenia ruchliwości cząsteczek wody i ograniczenia dyfuzji [2]. Tkanki takie cechują się wysoką intensywnością sygnału (IS) na obrazach przy wysokiej wartości współczynnika b i niskimi wartościami ADC (Apparent Diffusion Coefficient - pozorny współczynnik dyfuzji), co jest określane jako ograniczenie dyfuzji. Brak ograniczenia dyfuzji jest przyjmowany za cechę zmian łagodnych.

Ogólnie rzecz biorąc, wartość ADC zmian złośliwych jest niższa niż zmian łagodnych [2,7-23], ale nie ma jednej wartości ADC różnicującej (threshold) zmiany złośliwe od łagodnych. Celem pracy jest ocena wartości diagnostycznej obrazowania dyfuzji wody metodą rezonansu magne- 
tycznego (DWI MR) w różnicowaniu łagodnych i złośliwych zmian ogniskowych w wątrobie.

\section{Materiał i metody}

Analizą objęto 95 zmian ogniskowych w wątrobie u 51 chorych (21 mężczyzn i 30 kobiet) w wieku 21-78 lat (średnia wieku 58 lat). Zmian złośliwych było 71/95 (74,7\%), w tym 68 przerzutów i 3 ogniska raka wątrobowokomórkowego (HCC - Hepatocellular Carcinoma). Zmiany łagodne stanowiły 24/95 (25,3\%), w tym 15 naczyniaków, 2 FNH (focal nodular hyperplasia - ogniskowy przerost guzkowy), 1 gruczolak, 1 gruczolak dróg żółciowych, 1 ropień.

Rozpoznanie zmiany złośliwej postawiono na podstawie:

1. Weryfikacji mikroskopowej (histopatologicznej-59,2\% zmian, cytologicznej $-5,6 \%$ zmian).

2. Obserwacji:

a) rozpoznana choroba nowotworowa + progresja liczby i wielkości ognisk w wątrobie + wzrost poziomu markerów nowotworowych + kliniczna progresja choroby $-21,1 \%$ zmian,

b) rozpoznana choroba nowotworowa + progresja liczby i wielkości ognisk w wątrobie + wzrost poziomu markerów nowotworowych + kliniczna progresja choroby + wysoki wychwyt 18-FDG (SUV > 2,5) w badaniu PET/CT - 14,1\% zmian.

Rozpoznanie zmiany łagodnej postawiono na podstawie:

1. Weryfikacji mikroskopowej (histopatologicznej-29,2\% zmian).

2. Obserwacji:

c) stabilny obraz w badaniach obrazowych przez minimum 18 miesięcy + w tym czasie chorzy byli bez leczenia onkologicznego + poziom markerów nowotworowych był w granicach normy - 50\% zmian,

d) stabilny obraz w badaniach obrazowych przez minimum 18 miesięcy + w tym czasie chorzy byli bez leczenia onkologicznego + poziom markerów nowotworowych był w granicach normy + brak wychwytu FDG $w$ badaniu PET/CT - 20,8\% zmian.

Ostatecznie na podstawie badania histopatologicznego lub cytologicznego postawiono 53/95 rozpoznania 55,8\% (7 - zmian łagodnych, 46 - zmian złośliwych), a na podstawie obserwacji i innych badań postawiono $42 / 95$ rozpoznania 44,2\% (17 — zmian łagodnych, 25 — zmian złośliwych). Weryfikacja mikroskopowa wykonywana była średnio $28 \mathrm{dni}$ od badania MR.

Badania MR wykonane były aparatem o indukcji pola 1,5T (AVANTO TIM, Siemens). Badanie obejmowało obrazy T2 - w GRE (Gradient Echo), T2 — w TSE (Turbo Spin Echo), T1 - w GRE. U 19 chorych badanie dynamiczne wykonano z podaniem paramagnetycznego niespecyficznego narządowo środka kontrastowego, w fazie tętniczej, wrotnej i równowagi; w ten sposób oceniono 34/95 (35,8\%) zmian.
U 29 chorych podano paramagnetyczny hepatotropowy środek kontrastowy Gd-EOB-DTPA (Primovist, Bayer Schering Pharma AG). Dodatkowo wykonywano fazę opóźnioną badania - wątrobowokomórkową. Dyfuzja wykonywana była metodą EPI SE (Echo Planar Imaging Spin Echo), z wytłumieniem sygnału tkanki tłuszczowej. 76/95 (80 \%) zmian oceniono w obrazach dyfuzyjnych z maksymalną wartością b $\left(b_{\max }\right)=1000 \mathrm{~s} / \mathrm{mm}^{2}$, a 19/95 (20\%) zmian z maksymalną wartością b $\left(b_{\max }\right)=$ b 750 lub $800 \mathrm{~s} / \mathrm{mm}^{2}$.

Mapy ADC były liczone automatycznie przy pomocy programu dostarczonego przez producenta systemu MR. Fuzje map ADC z innymi obrazami wykonywano za pomocą oprogramowania dostarczonego przez producenta systemu MR.

Wrysowywany ręcznie obszar zainteresowania ROI był nie mniejszy niż $8 \mathrm{~mm}^{2}$ (tylko w kilku najmniejszych zmianach), w pozostałych zmianach większy niż $20 \mathrm{~mm}^{2}$. Gdy zmiana była jednorodna, pomiarem obejmowano jak największą jej część, nie przechodząc na prawidłowy miąższ wątroby. W zmianach niejednorodnych dokonywano pomiaru w obszarze o minimalnej (najniższej) wartości ADC, pomijając obszary martwicy. W zmianach mierzono ADC oraz IS na obrazach DW MRI przy każdej ze stosowanych wartości współczynnika b. Zmiany ograniczające dyfuzję uznawano za złośliwe.

W analizie statystycznej wykorzystano testy nieparametryczne, tj. test Wilcoxona/Kruskala-Wallisa dla porównań dwóch lub więcej grup oraz parametryczną analizę wariancji ANOVA z oceną post-hoc testem HSD Tukeya i metodę krzywych charakterystyki operacyjnej odbiornika (receiver operating characteristic curve - ROC). W analizie wykorzystano oprogramowanie JMP Base ver. 8. 0.1 (SAS Institute).

\section{Wyniki}

Ograniczenie dyfuzji stwierdzono w 65/95 (68,4\%) zmian. 62 z 65 (95\%) zmian ograniczających dyfuzję okazały się zmianami złośliwymi, a tylko 3 (5\%) — łagodnymi.

W grupie 30 zmian nieograniczających dyfuzji było 21 zmian łagodnych (70\%) i 9 złośliwych (30\%).

Dla parametru ograniczenia dyfuzji jako cechy zmiany złośliwej uzyskano: czułość 87,3\%, swoistość 87,5\%, wartość predykcyjną wyniku dodatniego 95,3\%, wartość predykcyjną wyniku ujemnego 70\%, dokładność diagnostyczną $87,4 \%$.

Ograniczenie dyfuzji występowało statystyczne istotnie częściej w zmianach złośliwych (62/71 = 87,3\%) niż łagodnych $(3 / 24=12,5 \%)(p<0,0001)$. Wykorzystując ograniczenie dyfuzji jako marker zmiany złośliwej, prawidłowo zaklasyfikowano 83/95 zmian (87,4\%) — 62 z 71 zmian złośliwych $(87,3 \%)$ i 21 z $24(87,5 \%)$ zmian łagodnych.

Wraz ze wzrostem wartości współczynnika b IS wszystkich zmian ogniskowych w wątrobie w obrazach DW MRI zmniejszała się. Największe średnie obniżenie wartości IS występowało w grupie naczyniaków i wynosiło 75\%, nato- 


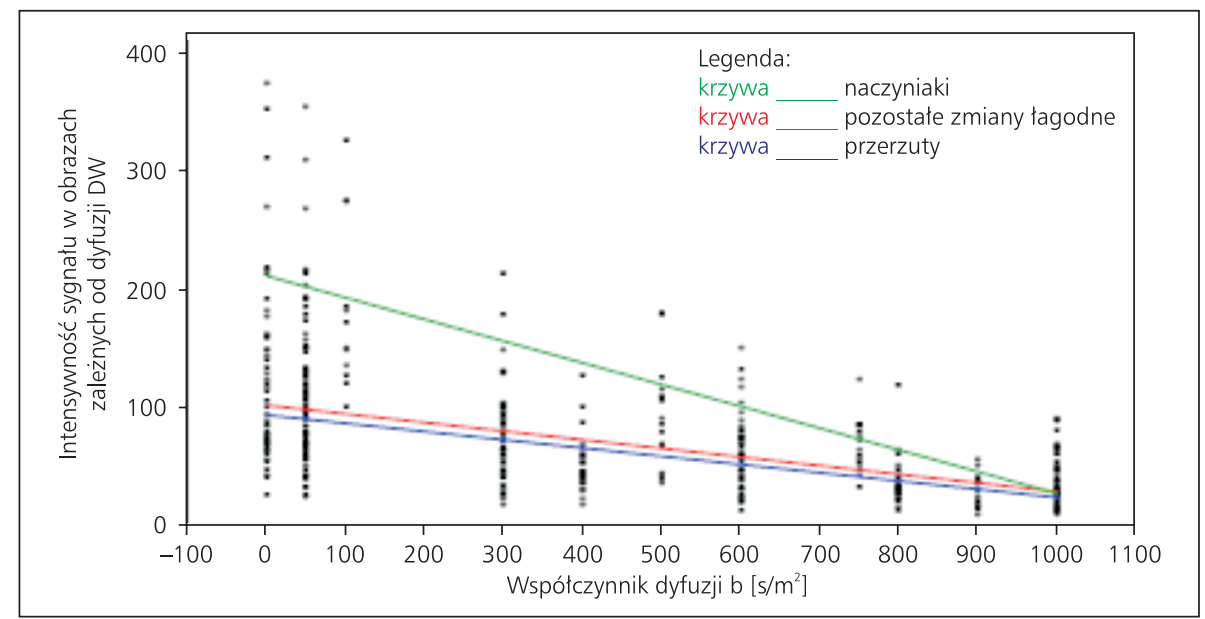

Rycina 1. IS w obrazach DW MRI przy różnych wartościach współczynnika b. Dokonano dopasowania metodą regresji liniowej — krzywa dla naczyniaków wykazuje znacznie większe nachylenie niż dla zmian przerzutowych i innych zmian łagodnych

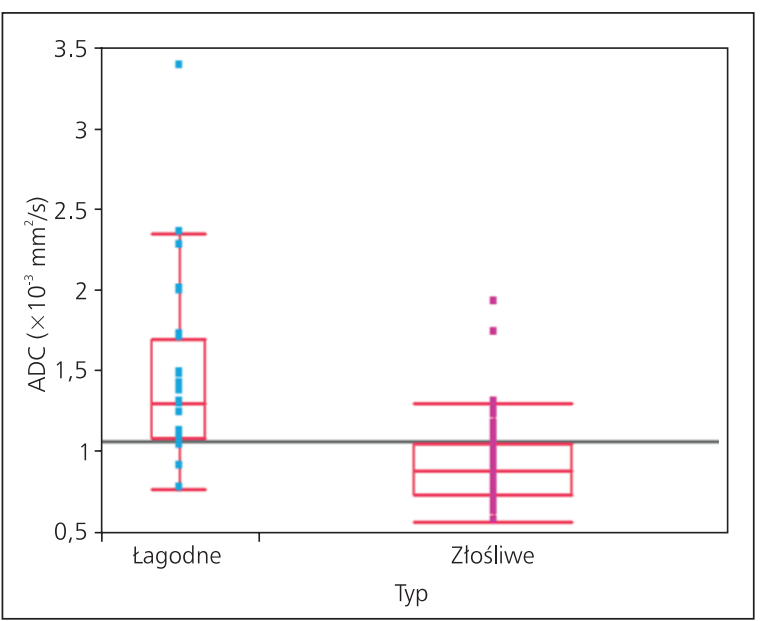

Rycina 2a. Mediany minADC zmian łagodnych i złośliwych w wątrobie

Mediana minADC zmian łagodnych $=1,29 \times 10^{-3} \mathrm{~mm}^{2} / \mathrm{s}$ Mediana minADC zmian złośliwych $=0,89 \times 10^{-3} \mathrm{~mm}^{2} / \mathrm{s}(\mathrm{p}<0,0001)$

miast najmniejsze, wynoszące 62\% — w zmianach przerzutowych ( $p=0,0014$ ) (ryc. 1).

Mediana oraz średnia minADC zmian łagodnych były istotnie statystycznie wyższe niż mediana oraz średnia minADC zmian złośliwych ( $p<0,0001$ ) (ryc. 2a i b). Optymalną wartością $A D C$ różnicującą (threshold) zmiany łagodne i złośliwe było $A D C=1,04 \times 10^{-3} \mathrm{~mm}^{2} / \mathrm{s}$. Uznając zmiany o wartości $A D C>1,04 \times 10^{-3} \mathrm{~mm}^{2} / \mathrm{s}$ za łagodne, a o wartości $A D C \leq 1,04 \times 10^{-3} \mathrm{~mm}^{2} / \mathrm{s}$ za złośliwe, prawidłowo zakwalifikowano 75,8\% zmian 20/24 (83,3 \%) zmian łagodnych oraz 52/71 (73,2\%) zmian złośliwych (czułość 75\%, swoistość - 92\%, PPV - positive predictive value - 96\%, NPV - negative predictive value - 55\%) (ryc. 3).

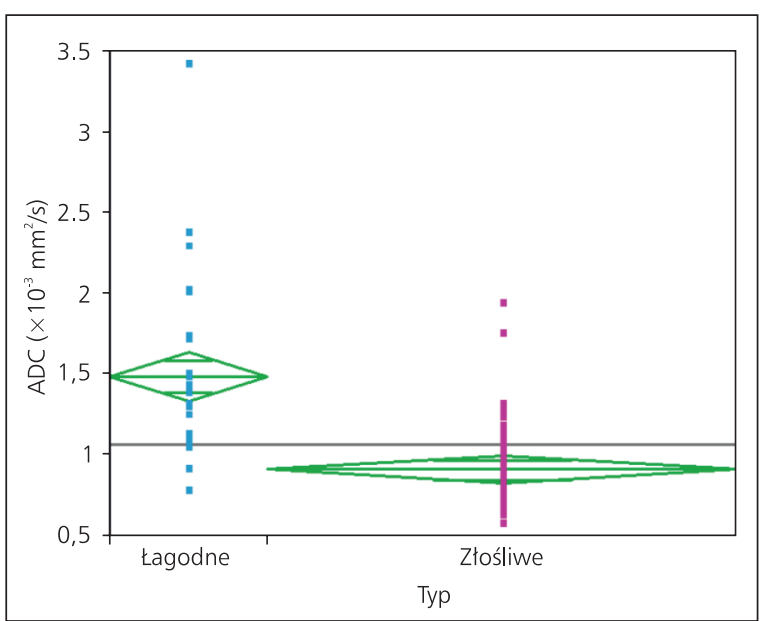

Rycina 2b. Średnie minADC zmian łagodnych i złośliwych w wątrobie Średnia minADC zmian łagodnych $\left(1,48 \times 10^{-3} \mathrm{~mm}^{2} / \mathrm{s} ; \mathrm{SD} \pm 0,58 \times 10^{-3}\right.$ $\mathrm{mm}^{2} / \mathrm{s}$ )

Średnia minADC zmian złośliwych $\left(0,92 \times 10^{-3} \mathrm{~mm}^{2} / \mathrm{s} ; \mathrm{SD} \pm 0,24 \times 10^{-3}\right.$ $\left.\mathrm{mm}^{2} / \mathrm{s}\right)(\mathrm{p}<0,0001)$

ADC $<0,77 \times 10^{-3} \mathrm{~mm}^{2} / \mathrm{s}$ nie stwierdzono $w$ zmianach łagodnych ADC $>1,91 \times 10^{3} \mathrm{~mm}^{2} / \mathrm{s}$ nie stwierdzono $w$ zmianach złośliwych

\section{Dyskusja}

Podstawowe obrazowanie MR tylko w części przypadków pozwala zróżnicować zmiany łagodne i złośliwe w wątrobie. Obrazowanie dyfuzji wody metodą MR (DW MRI) to nowe, nieinwazyjne badanie czynnościowe pozwalające odróżnić tkankę prawidłową i zmiany zapalne od nowotworu. W obrazowaniu DW MRI w zmianach złośliwych występuje zjawisko ograniczenia dyfuzji spowodowane zwiększoną ilością komórek w jednostce objętości oraz zwiększeniem stopnia nieregularności przestrzeni zewnątrzkomórkowej. 


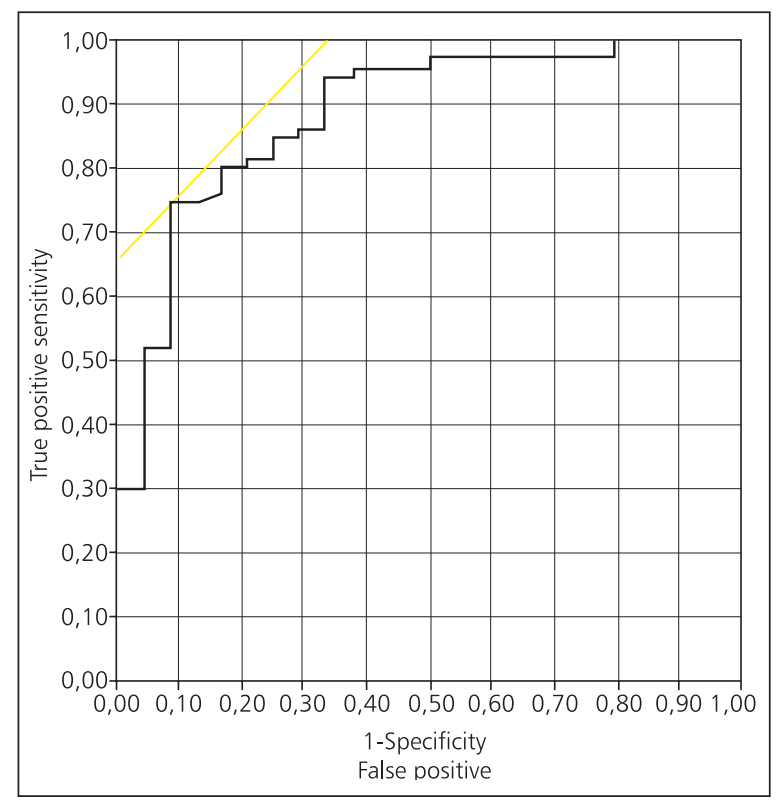

Rycina 3. Krzywa charakterystyki odbiornika (ROC - Receiver Operating Characteristic) dla wartości ADC odcinającej zmiany łagodne i złośliwe w wątrobie. Pole pod krzywą = 0,88586

W niniejszej pracy wykazano wysoką skuteczność obrazowania dyfuzji w różnicowaniu zmian łagodnych i złośliwych w wątrobie. Ograniczenie dyfuzji występowało statystyczne istotnie częściej w zmianach złośliwych (87,3\%) niżłagodnych $(12,5 \%)(p<0,0001)$, pozwalając rozpoznać zmiany złośliwe z czułością 87,3\%, swoistością 87,5\%. Wyniki te nie odbiegają od podawanych przez innych autorów [16-18].

Nie wszystkie nowotwory złośliwe ograniczają dyfuzję, toteż analiza tego zjawiska jest szczególnie przydatna dla uniknięcia wyników fałszywie negatywnych.

3 zmiany z 24 (12,5\%) ograniczających dyfuzję okazały się zmianami łagodnymi. Były to: ropień, naczyniak oraz okołowrotne zapalenie wątroby. W zmianach złośliwych ograniczenie dyfuzji pokrywa się ze wzmocnieniem kontrastowym. W ropniu ograniczenie dyfuzji wykazuje niewzmacniająca się kontrastowo część centralna, a wzmacniająca się kontrastowo część brzeżna nie ogranicza dyfuzji, co powoduje, że rozróżnienie tych zmian w badaniu MR najczęściej nie przedstawia trudności $[2,9,12,19,24]$.

Większość naczyniaków 14/15 (93,3\%) wykazywała cechy przyśpieszenia dyfuzji z wysokimi wartościami ADC, a jeden, który ograniczał dyfuzję, był dużą zmianą o średnicy $11 \mathrm{~cm}, \mathrm{z}$ obecnością potwierdzonych operacyjnie skrzeplin i zmian krwotocznych, które powodowały ograniczenie dyfuzji. W typowych naczyniakach stwierdza się zwykle przyśpieszenie dyfuzji, co jest tłumaczone stosunkowo dużą przestrzenią zewnątrznaczyniową, zawierającą ubogokomórkową tkankę łączną i substancje śluzowe [11, 25].

Większość zmian zapalnych nie ogranicza dyfuzji, i obecnie uważa się, że obrazowanie DW MRI jest skuteczną me- todą odróżnienia zmian zapalnych od nowotworowych [2, 7]. Ograniczające dyfuzję zapalenie okołowrotne w badaniu histopatologicznym, poza zwiększoną liczbą neutrofili, limfocytów i eozynofili, cechowało się bardzo dużą liczbą proliferujących przewodzików żółciowych. Wydaje się, że właśnie ta duża liczba "gęsto upakowanych" komórek przewodzików żółciowych mogła być przyczyną wystąpienia w tym wypadku ograniczenia dyfuzji.

W badaniach obrazowych w onkologii szczególny niepokój budzą wyniki fałszywie negatywne. W analizowanym materiale wszystkie 9/71 (12,7\%) zmian złośliwych, które nie ograniczały dyfuzji, były przerzutami. Dwa przerzuty raka jelita grubego, o średnicy $7 \mathrm{~mm}$ i $10 \mathrm{~mm}$, były izointensywne w stosunku do pozostałego miąższu wątroby tak w DWI przy b 800 i $1000 \mathrm{~s} / \mathrm{mm}^{2}$, jak i na mapach ADC. Pozostałych 7/9 (77,8\%) przerzutów było hiperintensywnych w stosunku do wątroby w obrazach DWI b $1000 \mathrm{~s} / \mathrm{mm}^{2}$ oraz na mapach ADC. W 4 z tych 7 przerzutów (57 \%) w badaniu histopatologicznym stwierdzono obszary martwicy niewidoczne makroskopowo. Pozostałe 3/7 (42,8\%) były hiperwaskularnymi, bardzo silnie wzmacniającymi się kontrastowo w fazie tętniczej przerzutami raka tarczycy. Brak ograniczenia dyfuzji w hiperwaskularnych przerzutach może być tłumaczony - podobnie jak w naczyniakach - budową. Prace analizujące związek unaczynienia guzów złośliwych wątroby z wartościami ADC są nieliczne i głównie dotyczą ognisk HCC $[20,26]$. Hiperperfuzja w dobrze i umiarkowanie zróżnicowanych hiperwaskularnych ogniskach HCC powoduje wzrost wartości ADC [20].

Wraz ze wzrostem wartości współczynnika b IS wszystkich zmian ogniskowych zmniejszała się, podobnie jak IS samej wątroby. Najwyższy średni spadek IS był w grupie naczyniaków (75\%), natomiast najniższy (62\%) w grupie przerzutów ( $p=0,0014)$. Zgodnie $z$ wiedzą autorów w literaturze nie ma prac analizujących znaczenie zmian IS ze wzrostem współczynnika b w diagnostyce różnicowej zmian ogniskowych w wątrobie.

Generalnie wartości ADC zmian złośliwych, także w wątrobie, są niższe niż zmian łagodnych [2, 8-16, 18, 19, 21-23]. Znalazło to potwierdzenie w naszym badaniu: średnia minADC zmian złośliwych $\left(0,92 \times 10^{-3} \mathrm{~mm}^{2} / \mathrm{s}\right)$ była statystycznie istotnie niższa niż zmian łagodnych $\left(1,48 \times 10^{-3} \mathrm{~mm}^{2} / \mathrm{s}\right)$ ( $p<0,0001)$.

W danych z piśmiennictwa średnie wartości ADC zmian złośliwych w wątrobie najczęściej mieszczą się w przedziale $1,01-1,39 \times 10^{-3} \mathrm{~mm}^{2} / \mathrm{s}[2,4,8-11,17,19,23,27]$.

Rozrzut wartości może być wytłumaczony wpływem ułożenia ROI na pomiar, ale także obecnością różnych typów zmian złośliwych w badanych grupach.

Bezpośredni wpływ na zmierzoną wartość ADC ma lokalizacja ROI [28]. Kwestia, czy mierzyć ADC całej zmiany, czy tylko części litej lub tylko części o minimalnych wartościach $A D C$, jest przedmiotem dyskusji. Co prawda, najczęściej 
dokonuje się pomiarów w litej części zmiany z pominięciem obszarów martwicy $[2,9,11,21]$, ale pomiar ADC całego guza łącznie z obszarem martwicy i zmianami torbielowatymi jest także stosowany $[2,8,15,16,18-20,27,29]$. Niektórzy autorzy nie podają dokładnie, jak był lokalizowany ROI $[2,25,26]$.

Średnia minADC zmianłagodnych w badanym materiale, wynosząca $1,48 \times 10^{-3} \mathrm{~mm}^{2} / \mathrm{s}\left(\mathrm{SD}+/-0,58 \times 10^{-3} \mathrm{~mm}^{2} / \mathrm{s}\right)$, jest niższa niż najczęściej podawane wartości ADC zmian łagodnych mieszczące się w przedziale od 2,19-2,55 × $10^{-3} \mathrm{~mm}^{2} / \mathrm{s}$ $[8,9,11,15,19]$. Ta niższa wartość ADC zmian łagodnych w badanej grupie chorych częściowo wynika z wyłączenia z analizy prostych torbieli wykazujących najwyższą wartość ADC spośród zmian ogniskowych w wątrobie [8, 11, 13, 15, 18]. Decyzja wydaje się uzasadniona, albowiem rozpoznanie prostej torbieli w badaniu MR nie sprawia trudności.

Wyznaczona za pomocą krzywej ROC optymalna wartość ADC (threshold) różnicująca zmiany łagodne i złośliwe wyniosła $1,04 \times 10^{-3} \mathrm{~mm}^{2} / \mathrm{s}$. W większości publikacji wartość $A D C$ różnicująca zmiany łagodne i złośliwe wątroby, z czułością i swoistością zbliżoną do przedstawionej w pracy, była wyższa i wynosiła $1,41-1,6 \times 10^{-3} \mathrm{~mm}^{2} / \mathrm{s}$, a nawet $2,3 \times 10^{-3} \mathrm{~mm}^{2} / \mathrm{s}[4,11,15,17,19,23]$.

Najwyższe parametry czułości (98 i 100\%) oraz swoistości (80 i 100\%) uzyskali Gourtsoyianni, przy odcinającej wartości ADC 1,47 × $10^{-3} \mathrm{~mm}^{2} / \mathrm{s}$, oraz Kim $-1,6 \times 10^{-3} \mathrm{~mm}^{2} / \mathrm{s}$, jednakże brak $w$ materiale tych autorów zmian łagodnych o stosunkowo niskiej wartości ADC, takich jak FNH i gruczolaki, oraz obecność torbieli spowodowały wysoką wartość ADC w grupie zmian łagodnych [11, 23].

\section{Wnioski}

W różnicowaniu łagodnych i złośliwych zmian ogniskowych w wątrobie najbardziej przydatnym parametrem obrazowania DW MRI jest ograniczenie dyfuzji - jako marker zmian złośliwych.

\section{Konflikt interesu: nie zgłoszono}

\section{Dr Justyna Rembak-Szynkiewicz}

Zakład Radiologii i Diagnostyki Obrazowej

Centrum Onkologii — Instytut im. Marii Skłodowskiej-Curie Oddział w Gliwicach

ul. Wybrzeże Armii Krajowej 15, 44-100 Gliwice

e-mail:remszyn@wp.pl

Otrzymano: 4 lutego $2014 \mathrm{r}$.

Przyjęto do druku: 25 czerwca $2014 \mathrm{r}$.

\section{Piśmiennictwo}

1. Knawy B, Shiffman M. Percutaneous liver biopsy in clinical practice. Liver International 2007; 27: 1166-1173.

2. Koh DM, Thoeny HC (red.).Diffusion-Weighted MR Imaging, Applications in the body, Springer-Verlag 2010.

3. Koh DM, Collins DJ. Diffusion-weighted MRI in the body: applications and challenges in oncology. AJR Am J Roentgenol 2007; 188:1622-1635.
4. Taouli B, Koh DM. Diffusion-weighted MR imaging of the liver. Radiology 2010; 254: 47-66.

5. Padhani A, Khan A. Diffusion-weighted (DW) and dynamic contrast-enhanced (DCE) magnetic resonance imaging (MRI) for monitoring anticancer therapy. Target Oncol 2010; 5: 39-52.

6. Rembak-Szynkiewicz J, Bobek-Billewicz B, Sokół M i wsp. Current methods of focal liver lesion diagnosis. Polish Annals of Medicine 2013; 20: 141-148.

7. Padhani A, Liu G, Koh DM i wsp. Diffusion-weighted magnetic resonance imaging as a cancer biomarker: consensus and recommendations. Neoplasia 2009; 11: 102-125.

8. Taouli B, Vilgrain V, Dumont E i wsp. Evaluation of liver diffusion isotropy and characterization of focal hepatic lesions with two single-shot echo-planar MR imaging sequences: prospective study in 66 patients. Radiology 2003; 226: 71-78.

9. Kandpal H, Sharma R, Madhusudhan KS, i wsp. Respiratory-triggered versus breath-hold diffusion-weighted MRI of liver lesions: comparison of image quality and apparent diffusion coefficient values. AJR 2009; 192: 915-922.

10. Holzapfel K, Bruegel M, Eiber M i wsp. Detection and characterization of focal liver lesions using respiratory-triggered diffusion-weighted MR imaging (DWI). MAGNETOM Flash 2/2008; 6-9.

11. Gourtsoyianni S, Papanikolaou N, Yarmenitis S. i wsp. Respiratory gated diffusion-weighted imaging of the liver: value of apparent diffusion coefficient measurements in the differentiation between most commonly encountered benign and malignant focal liver lesions. Eur Radiol 2008; 18: 486-492.

12. Chan J, Tsui E, Luk S i wsp. Diffusion-weighted MR imaging of the liver: distinguishing hepatic abscess from cystic or necrotic tumor. Abdominal Imaging 2001; 26: 161-165.

13. Bruegel M, Rummeny E. Hepatic metastases: use of diffusion-weighted echo-planar imaging. Abdom Imaging 2010; 35: 454-461.

14. Sutherland T, Steele E, van Tonder Fi wsp. Solid focal liver lesion characterization with apparent diffusion coefficient ratios. J Med Imag Radiat Oncol 2014; 58: 32-37.

15. Bruegel M, Holzapfel K, Gaa J i wsp. Characterization of focal liver lesions by $A D C$ measurements using a respiratory triggered diffusion-weighted single-shot echo-planar MR imaging technique. Eur Radiol 2008; 18 : 477-485.

16. Koh D, Scurr E, Collins D i wsp. Colorectal hepatic metastases: quantitative measurements using single-shot echo-planar diffusion-weighted MR imaging. Eur Radiol 2006; 16: 1898-1905.

17. Holzapfel K, Bruegel M, Eiber M i wsp. Characterisation of small (< $10 \mathrm{~mm}$ ) focal liver lesions: value of respiratory — triggered echo-planar diffusion-weighted MR imaging. Eur J Radiol 2010; 76: 89-95.

18. Holzapfel K, Reiser -Erkan C, Fingerle AA i wsp. Comparison of diffusion-weighted MR imaging and multidetector-row CT in the detection of liver metastases in patients operated for pancreatic cancer. Abdom Imaging 2011:36:179-184

19. Parikh T, Drew S, Lee VS i wsp. Focal liver Lesion detection and characterization with diffusion-weighted MR imaging: comparison with standard breath-hold T2-weighted imaging. Radiology 2008; 246: 812-822.

20. Nasu K, Kuroki Y, Tsukamoto T i wsp. Diffusion-weighted imaging of surgically resected hepatocellular carcinoma: imaging characteristics and relationship among signal intensity, apparent diffusion coefficient, and histopathologic grade. AJR 2009; 193: 438-444.

21. Chiu F, Jao J, Chen C i wsp. Effect of intravenous gadolinum - DTPA on diffusion-weighted magnetic resonance images for evaluation of focal hepatic lesions. J Comput Assist Tomogr 2005; 29: 176-180.

22. Vossen J, Buijs M, Liapi E i wsp. Receiver operating characteristic analysis of diffusion-weighted magnetic resonance imaging in differentiating hepatic hemangioma from other hypervascular liver lesions. J Comput Assist Tomogr 2008; 32: 750-756.

23. Kim T, Murakami T, Takahashi S i wsp. Diffusion-weighted single-shot echoplanar MR imaging for liver disease. AJR 1999; 173: 393-398.

24. Holzapfel K, Rummeny E, Gaa J.i wsp. Diffusion-weighted MR imaging of hepatic abscesses: possibility of different apparent diffusion coefficient (ADC) - values in early and mature abscess formation. Abdominal Imaging 2007; 32: 538-539.

25. Bozgeyik Z, Kocakoc E, Gul Y i wsp. Evaluation of liver hemangiomas using three different $b$ values on diffusion MR. Eur J Radiol 2010; 75: 360-363.

26. Vandecaveye V, De Keyzer F, Verslype C i wsp. Diffusion-weighted MR provides additional value to conventional dynamic contrast-enhanced MRI for detection of hepatocellular carcinoma. Eur Radiol 2009; 19: 2456-2466.

27. Hardie A, Naik M, Hecht E i wsp. Diagnosis of liver metastases: value of diffusion -weighted MRI compared with gadolinum-enhaced MRI. Eur Radiol 2010; 20: 1431-1441.

28. Schmid-Tannwald C, Dahi F, Jiang Y i wsp. DW-MRI of liver lesions: can a single ADC -value represent the entire lesion? Clinical Radiology 2014; 69: 492-498.

29. Goshima S, Kanematsu M, Kondo $\mathrm{H}$. i wsp. Hepatic hemangioma: $\mathrm{Cor}$ relation of enhancement types with diffussion-weighted MR findings and apparent diffusion coefficients. Eur J Radiol 2009; 70: 325-330. 